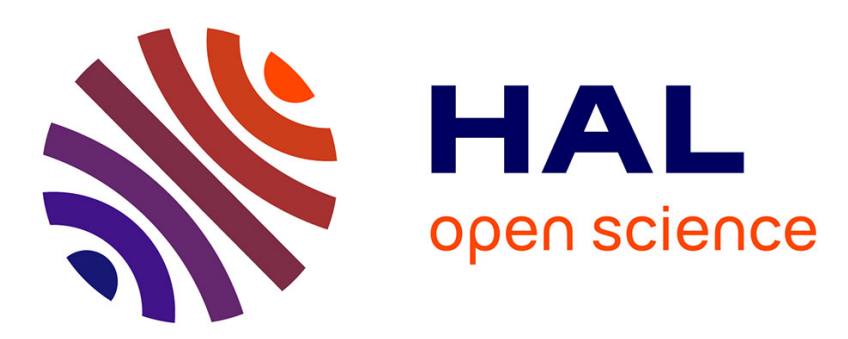

\title{
Quantification of human adenovirus and norovirus in river water in the north-east of France
}

Maryse Iris Sedji, Mihayl Varbanov, Marie Meo, Marius Colin, Laurence Mathieu, Isabelle Bertrand

\section{- To cite this version:}

Maryse Iris Sedji, Mihayl Varbanov, Marie Meo, Marius Colin, Laurence Mathieu, et al.. Quantification of human adenovirus and norovirus in river water in the north-east of France. Environmental Science and Pollution Research, 2018, 25 (30), pp.30497-30507. 10.1007/s11356-018-3045-4 . hal01867900

\section{HAL Id: hal-01867900 \\ https://hal.univ-lorraine.fr/hal-01867900}

Submitted on 29 Nov 2020

HAL is a multi-disciplinary open access archive for the deposit and dissemination of scientific research documents, whether they are published or not. The documents may come from teaching and research institutions in France or abroad, or from public or private research centers.
L'archive ouverte pluridisciplinaire HAL, est destinée au dépôt et à la diffusion de documents scientifiques de niveau recherche, publiés ou non, émanant des établissements d'enseignement et de recherche français ou étrangers, des laboratoires publics ou privés. 
1 Quantification of human adenovirus and norovirus in river water in the north-east of

2 France

3

4 Maryse Iris Sedji ${ }^{1}$, Mihayl Varbanov ${ }^{2}$, Marie Meo ${ }^{1}$, Leslie Ogorzaly ${ }^{1}$, Marius Colin $^{2}$,

$5 \quad$ Laurence Mathieu ${ }^{1,3 \dagger}$, Isabelle Bertrand ${ }^{1 \dagger^{* *}}$

6

$7 \quad{ }^{1}$ Université de Lorraine, CNRS, LCPME, Nancy, F -54000, France

$8 \quad{ }^{2}$ Université de Lorraine, CNRS, L2CM, Nancy, F-54000, France

$9 \quad{ }^{3}$ EPHE, PSL Research University, LCPME, UMR 7564, Vandoeuvre-lès-Nancy, F-54500,

10 France

11

$12 \uparrow$ These authors contributed equally to this work

13

14 *Corresponding author: Isabelle Bertrand, Laboratoire de Chimie Physique et Microbiologie 15 pour les Matériaux et l'Environnement (LCPME), UMR 7564 CNRS Université de Lorraine, 16 Faculté de Pharmacie, 5 rue Albert Lebrun, BP 80403, F-54000 Nancy, France. Tel: +33-3-72-74-73-52; Fax: +33-3-83-27-54-44; E-mail: isabelle.bertrand@ univ-lorraine.fr 


\section{Abstract}

Human adenoviruses (HAdVs) are a major cause of infection and have been proposed as viral indicators of water quality. Human noroviruses (NoV) are the main cause of viral acute gastroenteritis. Quantitative data on the environmental prevalence of both viruses are needed. The genomes of HAdVs, enteric adenovirus type 41 (HAdV41) and noroviruses of genogroups I and II (NoV GGI and GGII) were quantified over a six-month period in a river located in north-eastern France. The samples were collected downstream from the discharge of a wastewater treatment plant. The viruses were concentrated using a glass wool method and the viral genomes were quantified using digital droplet PCR (ddPCR). All river water samples $(15 / 15)$ were positive for the genomes of HAdVs, HAdV41, NoV GGI and NoV GGII. Concentrations of HAdVs, HAdV41 and NoV GII genomes were similar and HAdV41 represented $\sim 80 \%$ of HAdVs. Infectious HAdVs were quantified in these samples using an integrated cell culture - quantitative PCR method (ICC-qPCR); they were detected in 93\% $(14 / 15)$ and quantified in 53\% (8/15) of the samples. Thus, infectious HAdVs represented $0.3 \%$ to $12.2 \%$ of total HAdV particles detected by ddPCR. Infectious HAdV41 particles were found in $73 \%(11 / 15)$ of the samples. This common presence of pathogenic enteric viruses underlines the impact of wastewater discharge on quality of surface waters and may constitute a threat for human health. The relative abundance of genome of HAdV41 underlines the need for studies focusing on the specific detection of its infectious forms along water cycle.

Keywords: Adenovirus type 41; Norovirus; River water; Genome; Infectivity; ICC-qPCR; Quantification 


\section{Introduction}

HAdVs are a major cause of infections which can be fatal for immunocompromised individuals. They are associated with a wide range of clinical illnesses including upper and lower respiratory diseases, conjunctivitis, cystitis and gastroenteritis. All HAdVs are excreted in faeces for an extended period of time even if diarrhoea is not present (Mena and Gerba 2009; Rodriguez-Lazaro et al. 2012). A recent study has shown the role of intestinal lymphocytes as a reservoir for HAdV persistence and reactivation, whereas the intestinal epithelium is the main site of viral proliferation preceding dissemination in immunocompromised patients (Kosulin et al. 2016). HAdVs are non-enveloped viruses characterized by a double-stranded DNA genome. They belong to the family Adenoviridae of the genus Mastadenovirus and are divided into seven species (A to G). Ninety genotypes are currently proposed by the Human Adenovirus Working Group (hadvwg.gmu.edu; update July 2018).

HAdVs have been proposed as a viral indicator for water quality (Bofill-Mas et al. 2010; La Rosa et al. 2010; Wyn-Jones et al. 2011; Rusiñol et al. 2015; Rames et al. 2016; Farkas et al. 2018). Indeed, these viruses reach at least the six following criteria: i) presence from wastewater to surface water, ii) lack of seasonality in wastewater, iii) high resistance to ultraviolet disinfection, iv) higher abundance relative to other enteric viruses, v) availability of molecular methods and culture assays, and vi) human host specificity (Rames et al. 2016). HAdVs seem to be highly persistent in the environment and may reflect the behaviour of persistent enteric viruses (Farkas et al. 2018). Eight viral types of HAdVs belonging to A, C and $\mathrm{F}$ species have been reported mainly in water (Ogorzaly et al. 2015). The most prevalent HAdV type detected in wastewater and surface water is enteric type HAdV41 which causes diarrhoea (Rames et al. 2016). Thus, HAdV41 genome was detected in $92 \%$ to $96 \%$ of wastewater samples positive for HAdVs in Italy (Iaconelli et al. 2017a) and Japan (Haramoto et al. 2007), and in 100\% of the hospital wastewater samples in Tunisia (Ibrahim et al. 2018). 
HAdV41 was also detected in $100 \%$ of the wastewater samples positive for HAdVs in Luxembourg $(\mathrm{n}=8)$ with a relative abundance estimated to more than $80 \%$ using nextgeneration sequencing (Ogorzaly et al. 2015). This enteric type is also highly prevalent in surface water; it was detected in $94 \%$ to $100 \%$ of river water samples positive for HAdVs in Luxembourg (Ogorzaly et al. 2015), Italy (La Rosa et al. 2017) and Japan (Haramoto et al. 2007). HAdV41 represented 12 to $77 \%$ of overall HAdVs in lake samples collected at recreational beaches in the USA (Xagoraraki et al. 2007). The frequent presence of HAdV41 in recreational hot springs in Taiwan has also been recently described (Shih et al. 2017). Environmental data on HAdVs have been mainly obtained using molecular methods only; this led to the absence of information about the infectious status of HAdVs in environmental samples (Girones et al. 2010; Ogorzaly et al. 2015). Various methods could be combined with molecular methods to favour the detection of infectious enteric viruses. Most of them are based on the increased permeability of the capsid to intercalating dyes such as ethidium monoazide (EMA) or propidium monoazide (PMA) (Prevost et al. 2016).

Intercalating dyes may be useful for the discrimination between infectious and non-infectious viruses such as HAdVs if the inactivation treatment alters the capsid with an increase in its permeability (Leifels et al. 2016). This approach could also be applied for the monitoring of viruses for which cell culture method could not be easily applied on environmental samples or does not exist yet (Prevost et al. 2016).

Infectious HAdVs can be quantified using cell culture methods but long periods of time are required for HAdVs to produce cytopathic effects (Rames et al. 2016). The integrated cell culture-quantitative polymerase chain reaction (ICC-qPCR) approach combines cell culture with qPCR. This approach does not require the observation of cytopathic effects and allows the reduction of the incubation period down to one to three days even for environmental samples (Rodriguez et al. 2013; Fongaro et al. 2015; Ogorzaly et al. 2015). Two analytical approaches are described for HAdVs based on the detection of either viral DNA (Greening et 
al. 2002) or viral mRNA (Ko et al. 2003) in host cells. Viral DNA detection is easily performed, but it requires monitoring of the increase in initial genome copy numbers over time thus reflecting viral replication upon infection (Ogorzaly et al. 2013). The presence of viral mRNA in host cells is evidence of viral infection, but mRNA detection involves a reverse transcription step and an enzymatic digestion of contaminating DNA, whose efficiency has to be checked. Moreover, the variation in mRNA concentration during the virus replication cycle and the susceptibility of such molecules to degradation under some conditions require the use of housekeeping genes as cell-based positive control for mRNA expression (Rodriguez et al. 2013). Another technical aspect of major importance in the use of the ICC-qPCR method for the detection of infectious HAdVs in environmental samples concerns the cell line used. Indeed, the 293 cell line, also called HEK293 or Graham 293 (G293), seems to be the most suitable for the detection of a wide diversity of HAdVs occurring in water samples, especially HAdV41 (Ogorzaly et al. 2015). A549 and BGM cell lines are also frequently used for the detection of infectious HAdVs using ICC-qPCR approach (Greening et al. 2002; Lee et al. 2004; Lee et al. 2005; Wyn-Jones et al. 2011; Fongaro et al. 2013; Fongaro et al. 2015), but their use may result in a lack of detection of enteric adenoviruses types 40 and 41 (Wyn-Jones et al. 2011). The infection of permissive cells with serial dilutions of a known HAdVs suspension in parallel with the sample allows the quantification, and not only the detection, of infectious HAdVs. Whereas the ICC-qPCR assay is currently used for quantifying infectious HAdVs in laboratory strains (Gerrity et al. 2008; Li et al. 2009; Ryu et al. 2015), very few studies have applied it for the quantification of infectious HAdVs in environmental water samples (Fongaro et al. 2013; Rodriguez et al., 2013; Fongaro et al., 2015).

Although river waters are commonly used for production of drinking water or culture irrigation, data are still limited concerning the concentrations of HAdVs in such samples. The occurrence and concentrations of HAdVs have been compared to those of other pathogenic 
enteric viruses (e.g. noroviruses, enteroviruses) but mainly in wastewaters (Rames et al. 2016). Moreover, data are lacking on the relative abundance of infectious HAdVs.

Comparison between HAdVs and other pathogenic enteric viruses, in particular noroviruses, in terms of total particles and data about concentrations of infectious HAdVs are needed for their evaluation as viral indicators of water quality.

In this context, the present study aimed to improve the knowledge about HAdVs in environmental samples. First, the genomes from all types of HAdVs, enteric type HAdV41, NoV GGI and NoV GGII were quantified in 15 river water samples in order to give elements in the evaluation of HAdVs as potential indicators of viral contamination. Second, a one-day ICC-qPCR assay allowing the quantification of infectious HAdVs was applied on the same river samples. This method allowed us to estimate the relative abundance of infectious HAdVs among total HAdV particles. Third, the prevalence of infectious HAdV41 was also investigated in these river water samples.

\section{Materials and methods}

\section{Cell line and virus}

Human embryonic kidney cell line 293A (Thermo Fisher Scientific, R705-07) was used in this study between passages 15 and 30. Cell line 293A is a sub-clone of 293 cells with a rather flat morphology which strongly adheres to conventional culture surfaces. They were cultured in Dulbecco's modified Eagle's medium (DMEM) containing a high glucose concentration and Glutamax (Gibco). This medium was supplemented with 5\% of fotal bovine serum (FBS, Gibco) and $1 \%$ of non-essential amino acids (NEAA, Gibco).

Human adenovirus type 2 (HAdV2; HPACC, NCPV\#213) was chosen since it is a common type in environmental water samples and one of the most studied types in lab-scale experiments. HAdV2 was propagated in 293A cells after three days of culture. The culture medium was supplemented with 2\% FBS for HAdV2 replication. After three to four days, 
FBS was added at a $20 \%$ final concentration just before three freeze/thaw cycles. A centrifugation $(2,000 \times \mathrm{g}$ for $10 \mathrm{~min})$ was then performed to remove cell debris from the viral lysate. The supernatant was supplemented with sterile glycerol at a 30\% final concentration, aliquoted $(1.2 \mathrm{~mL})$ and stored at $-80^{\circ} \mathrm{C}$.

\section{River water samples}

Over a six-month period (January-June 2016), a total of 15 river water samples (20 L) were collected in the Meurthe River in Maxéville. The samples were collected downstream from the metropolitan wastewater treatment plant (WWTP) ( 250,000 inhabitants, MaxévilleNancy) (Fig. 1 in Supplementary material). The wastewater treatment is based on activated sludge followed by removal of nitrogen and phosphorus. The metropolitan area is equipped with rainwater collection systems with a retention capacity of $180,000 \mathrm{~m}^{3}$ to reduce the effect of heavy rain events on the operation of the WWTP. The average volume of treated wastewater discharged by the WWTP is $\sim 100,000 \mathrm{~m}^{3} /$ day and the mean flow of this river ranges from $\sim 65.7 \mathrm{~m}^{3} / \mathrm{s}$ in January to $\sim 30.6 \mathrm{~m}^{3} / \mathrm{s}$ in June (mean of data collected from 1960 to 2018, http://www.hydro.eaufrance.fr/stations/A6941020\&procedure=synthese).

\section{Quantification of infectious HAdVs in laboratory strain using the most probable}

\section{number assay}

The Most Probable Number (MPN) assay was performed to determine the infectious titre of the laboratory strain that was then used for the standard of the ICC-qPCR method. This method is used for the quantification of infectious enteric viruses (Gassilloud et al 2003; Ogorzaly et al 2010; Brié et al 2017). In our case, the MPN assay was performed in 96-well microplaques using 293A cells. Fifty-microlitre portions of successive logarithmic dilutions of each sample were added to $200 \mu \mathrm{L}$ of preparation containing $3 \times 10^{4} 293 \mathrm{~A}$ cells $/ \mathrm{mL}$ in 
DMEM containing 2\% FBS. Each dilution was seeded in 40 wells. Plates were incubated in $5 \% \mathrm{CO}_{2}$ at $37^{\circ} \mathrm{C}$ for 11 days and then examined for cytopathic effects. The number of wells with cytopathic effects were counted and the MPNCU (most probable number of cytopathic units) was calculated. The final result of each sample analysed was expressed as the geometric mean of the MPNCU per millilitre. The quantification limit of this method is of 1.5 MPNCU/mL.

\section{Virus concentration from river water samples}

A glass wool method was used for virus concentration, as previously described; this method is well adapted to the detection of infectious HAdVs using cell culture methods (Wyn-Jones et al 2011; Ogorzaly et al 2013). Briefly, river samples (20 L) were acidified with $1 \mathrm{M} \mathrm{HCl}$ to pH 3.5 and $10 \mathrm{~g}$ of sterile glass wool was used for the filtration column. When the entire sample had passed through the filter HAdVs were eluted from the glass wool by slow passage of $200 \mathrm{~mL} 3 \%$ beef extract (w/v) at $\mathrm{pH} 9.5$ in $0.05 \mathrm{M}$ glycine buffer. The eluate was flocculated by the addition of $1 \mathrm{M} \mathrm{HCl}$ to $\mathrm{pH} 3.5$. The protein floc, containing viruses, was recovered by centrifugation $(7,000 \times g$ for $30 \mathrm{~min})$ and dissolved to a final volume of $20 \mathrm{~mL}$ DMEM. The suspension was passed through a combination of pre-filter ( $5 \mu \mathrm{m}$, Sartorius Minisart) and membranes (1.2 and $0.45 \mu \mathrm{m}$, Sartorius Minisart) before freezing at $-80^{\circ} \mathrm{C}$.

\section{Genome extraction in river water concentrates}

For the quantification of the viral genomes in the river water concentrates, a $1 \mathrm{~mL}$ aliquot was mixed with $2 \mathrm{~mL}$ of lysis buffer and incubated at room temperature for $10 \mathrm{~min}$. The sample was then mixed with $3 \mathrm{~mL}$ of phenol/chloroform/isoamyl alcohol (24:5:1; Acros Organics) and centrifuged $(2,000 \times g$ for $5 \mathrm{~min})$. Viral DNA and RNA extraction was then performed on the supernatant using a NucliSens Magnetic extraction kit (bioMérieux). The elution step was carried out with $100 \mu \mathrm{L}$ of the appropriate buffer and the extracted nucleic acids were 
immediately stored at $-80^{\circ} \mathrm{C}$. This kit is well adapted for the extraction of viral genomes and can be easily combined to the phenol/chloroform/isoamyl alcohol pre-treatment applied on the water concentrates.

\section{Genome quantification in river water concentrates using digital droplet PCR}

The digital droplet PCR approach (dd-PCR) was performed for the quantification of the genomes of HAdVs, HAdV41, NoV GGI and NoV GGII in river water concentrates. For HAdVs, the assay described by Hernroth et al. (2002) using degenerated primers (AdF and $\mathrm{AdR})$ and a TaqMan probe (Ad/ACDEF) was used. This assay is based on the amplification of the hexon gene and recognizes most HAdVs (Bofill-Mas et al. 2006). For HAdV41, the assay based on the amplification of the fibre protein was designed in our laboratory. The TaqMan MGB probe was: 5'-FAM CTT CGC CTT CAA AGT GC-MGB NFQ-3' (position 30415-30431 on AdV41 sequence, KY316161.1) and the primers were: forward 5'-CGC CCC ACT TAA TGC TGA CA-3' (position 30387-30406), reverse primer 5'-TCC ACT AGT CCA AGA GGT GCA-3' (position 30432-30452). Primer and probe sequences were subsequently confirmed for specificity using BLAST. NoV GGI and NoV GGII genomes were quantified using primers and probes described in ISO/TS Standard 15216-1:2013 (International Organization for Standardization, 2013). Amplifications were performed in a 20 $\mu \mathrm{L}$ reaction mixture containing $5 \mu \mathrm{L}$ of template DNA for HAdVs and HAdV41 or RNA for NoV GGI and GGII, and $15 \mu \mathrm{L}$ of ddPCR ${ }^{\mathrm{TM}}$ Supermix for Probes (BIO-RAD) for HAdVs and HAdV41 and One-Step RT-ddPCR ${ }^{\mathrm{TM}}$ Kit for Probes (BIO-RAD) for NoV GGI and GGII. The reaction mix contained $0.9 \mu \mathrm{M}$ of each primer, $0.225 \mu \mathrm{M}$ of probe for HAdVs and 0.3 $\mu \mathrm{M}$ of probe for NoV. The samples were placed in the droplet generator using $70 \mu \mathrm{L}$ of generator oil. The resulting picolitre droplet emulsions $(40 \mu \mathrm{L})$ were transferred to a Veriti 96-Well Thermal Cycler (Applied Biosystems). Viral DNA amplification was performed using the following conditions: 10 min hold at $95^{\circ} \mathrm{C}, 40$ cycles of $94^{\circ} \mathrm{C}$ for $30 \mathrm{~s}$ then $55^{\circ} \mathrm{C}$ for 
$60 \mathrm{~s}$ and finally a $10 \mathrm{~min}$ hold at $98^{\circ} \mathrm{C}$ with a ramp rate set at $70 \%$ between each step. For

viral RNA amplification, the reverse transcription was performed with 60 min hold at $50^{\circ} \mathrm{C}$.

After amplification the plate was transferred to QX100TM Droplet Reader (BIO-RAD) using QuantaSoft ${ }^{\mathrm{TM}}$ Software (BIO-RAD) to measure the number of positive and negative droplets based on fluorescence amplitude. Each sample was analysed undiluted and after a 10-fold dilution. Negative and positive controls were included in each experiment to ensure no contamination and good reproducibility of the extractions and PCR assays. The genome concentrations obtained with this method were given in genome copies (gc) per unit volume.

\section{Quantification of infectious HAdVs using ICC-qPCR method}

For the ICC-qPCR assay the river water samples were analysed concomitantly with a 10-fold dilution series of the laboratory strain HAdV2 used as standard in order to quantify infectious HAdVs. The standard was made with concentrations ranging from $10^{5}$ to 10 MPNCU/mL. A $1 \mathrm{~mL}$ volume of standard or river water sample was inoculated per well of six-well plates $\left(\mathrm{Nunc}^{\mathrm{TM}}\right.$ ) containing two-day-old 293A cells, with a growth area of $9.6 \mathrm{~cm}^{2} . \mathrm{A}$ negative control was included in all our experiments, consisting in the inoculation of cells with $1 \mathrm{~mL}$ of DMEM medium. After inoculation, plates were incubated for $2 \mathrm{~h}$ at $37^{\circ} \mathrm{C}$ with $5 \% \mathrm{CO}_{2}$ for adsorption of viral particles. Afterwards, the inoculum was removed, and the cells were washed twice with $2 \mathrm{~mL}$ of DMEM. Finally, $2 \mathrm{~mL}$ of DMEM containing $2 \%$ of FBS and supplemented with a $1 \%$ final concentration of an antibiotic-antimycotic solution $(10,000$ units/mL of penicillin, 10,000 units $/ \mathrm{mL}$ of streptomycin and $25 \mu \mathrm{g} / \mathrm{mL}$ of amphotericin B; Gibco) were added to each well. For the wells marked as $T_{0}$ viral DNA was immediately extracted. The wells marked as $T_{24 h}$ were incubated at $37^{\circ} \mathrm{C}$ with $5 \% \mathrm{CO}_{2}$ for one day, before viral DNA extraction which was performed using QIAamp viral RNA mini kit (Qiagen). This kit allows the extraction of viral DNA in particular from infected cell cultures (Ogorzaly et al. 2013, 2015). The culture medium was discarded from each well by aspiration 
and the 293A cells - potentially infected by viruses - were covered with $1 \mathrm{~mL}$ of lysis buffer (AVL buffer + Carrier RNA) for 15 min. Viral nucleic acids were eluted in $100 \mu \mathrm{L}$ of the appropriate buffer, according to manufacturer's instructions. The extracts were immediately stored at $-80^{\circ} \mathrm{C}$. Quantification of the HAdV and HAdV41 genomes in the cell culture samples was performed by a generic real-time PCR system using the same primers and probes as those described for ddPCR. Amplifications were performed in a $25 \mu \mathrm{L}$ reaction mixture containing $10 \mu \mathrm{L}$ of template DNA and $15 \mu \mathrm{L}$ of TaqMan Universal MasterMix (Applied Biosystems) containing $0.9 \mu \mathrm{M}$ of each primer and $0.225 \mu \mathrm{M}$ of TaqMan probe. Temperature cycles were performed in CFX96 Touch $^{\mathrm{TM}}$ Real-Time PCR Detection System (BIO-RAD). PCR amplification was performed at $95^{\circ} \mathrm{C}$ for $10 \mathrm{~min}$, followed by 45 cycles of $15 \mathrm{~s}$ at $95^{\circ} \mathrm{C}$ and $60 \mathrm{~s}$ at $55^{\circ} \mathrm{C}$. Negative and positive controls were included in each experiment to ensure no contamination and good reproducibility of the extractions and real-time PCR steps.

Samples were considered positive for infectious HAdVs if a decrease in their quantification cycle $(\mathrm{Cq})$ values was observed between $T_{0}$ and $T_{24 h}$. Three wells were used for each dilution of the standard (one $T_{0}$ and two $T_{24 h}$ ). For each environmental sample, four wells were each infected with $1 \mathrm{~mL}$ of concentrate (one $T_{0}$ and three $T_{24 h}$ ). The concentrations obtained with this method were given in equivalent Most Probable Number of Cytopathic Unit (eqMPNCU) per millilitre. The quantification limit of this method was determined prior to the analysis of the river water samples.

\section{Statistical analysis}

The statistical analysis was performed using IBM SPSS Statistics version 23.0 Software. A Wilcoxon signed rank test, a Spearman rank correlation test and linear regression tests were performed to compare the viral genome concentrations of HAdVs, HAdV41, NoV GGI and NoV GGII in the river water concentrates. 


\section{Results}

\section{Quantification of viral genomes in the river water samples}

281

282

The $\mathrm{pH}$ and the temperature of the river water samples were measured prior to virus concentration; the mean $\mathrm{pH}$ value was $8.2 \pm 0.4$ and the mean water temperature was $12.0 \pm 3.5^{\circ} \mathrm{C}$. The cumulative precipitation two days prior to sampling reached $4.1 \pm 4.2 \mathrm{~mm}$ (Table 1 in Supplementary material).

Prior to the quantification of infectious HAdVs in the river water samples, the genome concentrations of HAdVs and HAdV41 were determined using ddPCR method (Fig. 1). The 15 samples were positive for these two targets with mean concentrations reaching $3.6 \times 10^{3} \pm 4.4 \times 10^{3} \mathrm{gc} / \mathrm{L}$ for HAdVs and $2.9 \times 10^{3} \pm 2.9 \times 10^{3} \mathrm{gc} / \mathrm{L}$ for HAdV41. The concentrations ranged from $1.1 \times 10^{2} \mathrm{gc} / \mathrm{L}\left(\mathrm{S}-14\right.$ [Sample 14]) to $1.4 \times 10^{4} \mathrm{gc} / \mathrm{L}(\mathrm{S}-11)$ for HAdVs and from $1.3 \times 10^{2} \mathrm{gc} / \mathrm{L}(\mathrm{S}-14)$ to $9 \times 10^{3} \mathrm{gc} / \mathrm{L}$ (S-9 and S-11) for HAdV41. The genome concentrations of NoV GGI and NoV GGII were also evaluated in these samples (Fig. 1). The mean concentrations reached $6.1 \times 10^{2} \pm 7.4 \times 10^{2} \mathrm{gc} / \mathrm{L}$ for NoV GGI and $3.7 \times 10^{3} \pm 3.2 \times 10^{3} \mathrm{gc} / \mathrm{L}$ for NoV GGII. The lowest genome concentrations were systematically observed for NoV GGI (P-value $=0.001$, Wilcoxon signed rank test). The genome concentrations obtained with undiluted and 10-fold diluted samples suggested that our ddPCR assays were not impacted by inhibitory substances. These samples had been collected between January and June, but no difference in the concentration was noticed between the winter and spring periods for any virus. Similarly, no relation was observed between the cumulative precipitation and the genome concentrations for any virus. In order to assess correlation between these viruses, Spearman rank and linear regression analyses were performed on these data (Table 2 in Supplementary material). The strongest correlation was observed between HAdVs and HAdV41 with an $r_{s}$ value of 0.943 (P-value $<0.01$ ) and an $R^{2}$ value of 0.94 (Fig. 3a). The comparison between the genome 
concentrations of HAdVs and HAdV41 showed that the enteric type HAdV41 represented $\sim 80 \%$ of HAdVs detected in these river water samples. A strong correlation was also observed between NoV GGI and NoV GGII and between HAdV41 and NoV GGII with $r_{s}$ values reaching $0.844(\mathrm{P}$-value $<0.01)$ and $0.808(\mathrm{P}$-value $<0.01)$, respectively. Moreover, $R^{2}$ values of 0.59 and 0.61 were found between HAdV41 and NoV GGII (Fig. 3b) and between NoV GGI and NoV GGII (Fig. 3c), respectively. The $R^{2}$ value reached 0.50 between HAdVs and NoV GGII. These results suggested an interrelation between NoV GGII and HAdV41 in these river water samples.

\section{Validation of the ICC-qPCR assay on HAdV2 suspension}

The ICC-qPCR assay was performed with 10-fold serial dilutions of the HAdV2 laboratory strain $(\mathrm{n}=17)$ ranging from $10^{5}$ to $10 \mathrm{MPNCU} / \mathrm{mL}$ which were tested in duplicate in each assay. At $T_{0}$, all samples were positive (i.e. Cq value < 45) for concentrations ranging from $10^{5}$ to $10^{3} \mathrm{MPNCU} / \mathrm{mL}$, whereas only four assays out of 17 were positive for $10^{2} \mathrm{MPNCU} / \mathrm{mL}$. For $10 \mathrm{MPNCU} / \mathrm{mL}$, all tests were negative (i.e. Cq value $\geq 45$ ) at $T_{0}$ (data not shown). The Cq value at $T_{0}$ showed the quantity of HAdVs bound to cells just after their inoculation. Between $T_{0}$ and $T_{24 h}$, a decrease in the Cq value was noticed for concentrations ranging from $10^{5}$ to $10 \mathrm{MPNCU} / \mathrm{mL}$, reflecting the replication of viral DNA in the host cells. When no infectious HAdVs were inoculated onto the cells, samples were negative at $T_{0}$ and $T_{24 h}$ (data not shown). The Cq values obtained at $T_{24 h}$ were represented as a function of the concentration of infectious HAdV2 inoculated onto cells (Fig. 1); a linear response was obtained from $10^{5}$ to $10 \mathrm{MPNCU} / \mathrm{mL}$. The mean $\mathrm{Cq}$ values ranged from 17.3 (10 $\left.0^{5} \mathrm{MPNCU} / \mathrm{mL}\right)$ to 30.3 (10 MPNCU/mL). The slope of this ICC-qPCR standard curve was -3.33 , with a squared correlation coefficient $\left(R^{2}\right)$ of 0.9981 . An increase in the Cq value was observed between $T_{0}$ and $T_{24 h}$ in 15 assays out of 17 at a concentration of $10 \mathrm{MPNCU} / \mathrm{mL}$ which evidenced that this ICC-qPCR method allowed the quantification of infectious HAdVs 
with a quantification limit of 10 eqMPNCU/mL. Thus, we could expect a quantification limit of 10 eqMPNCU/L of river water.

The ICC-qPCR method was then compared to the MPN method on the basis of HAdV2 suspensions exposed to different experimental conditions. A titration was performed with both methods just after production for one suspension. Concentrations of infectious HAdVs reached $1.1 \times 10^{10}$ eqMPNCU/mL and $4.5 \times 10^{9} \mathrm{MPNCU} / \mathrm{mL}$ with the ICC-qPCR and MPN methods, respectively. Thus, the concentration obtained with the ICC-qPCR method was twice that obtained with the MPN assay. The titrations performed with two suspensions after storage at $-80^{\circ} \mathrm{C}$ for several weeks showed concentrations of $8.3 \times 10^{8}$ eqMPNCU/mL (suspension 1) and $1.5 \times 10^{9}$ eqMPNCU/mL (suspension 2) using ICC-qPCR method and of $6.9 \times 10^{8} \mathrm{MPNCU} / \mathrm{mL}$ (suspension 1) and $2.0 \times 10^{9} \mathrm{MPNCU} / \mathrm{mL}$ (suspension 2) using the MPN method. For these two suspensions, the concentrations detected with the ICC-qPCR method reached $120 \%$ and $75 \%$ of those observed with the MPN method.

\section{Quantification of infectious HAdVs in the river water samples}

Infectious HAdVs were then quantified in the 15 river samples using the ICC-qPCR assay. From the Cq values obtained at $T_{0}$ and $T_{24 h}, 14$ samples (93\%) were considered as positive for infectious HAdVs. Among them, eight samples (53\%) contained between $1.5 \times 10^{1}$ and $4.1 \times 10^{2}$ eqMPNCU/L and the other six were below the quantification limit (Fig. 4). When quantifiable, infectious HAdVs represented between $0.3 \%$ and $12.2 \%$ of total HAdVs. Infectious HAdV41 could not be specifically quantified using our ICC-qPCR assay since it was based on a standard curve obtained with HAdV2. However, the quantification of the HAdV41 genome in infected cells at $T_{0 h}$ and $T_{24 h}$ allowed us to determine the number of samples positive for infectious HAdV41. Thus, an increase in the concentration of HAdV41 genome was observed in infected cells between $T_{0}$ and $T_{24 h}$ for 11 samples (73\%); they were marked with an asterisk in Fig. 4. Infectious HAdV41 particles were detected in the eight 
samples in which infectious HAdVs were quantified and in three out of the six samples containing infectious HAdVs below the quantification limit.

\section{Discussion}

The present work aimed to contribute to the evaluation of HAdVs as viral indicators of water quality. For this purpose, comparison between the genome concentrations of human NoV GGI and GGII, which are the main cause of viral acute gastroenteritis, and HAdVs were performed in river water samples characterised by a recent faecal contamination. Infectious HAdVS were also quantified in our river water samples using an ICC-qPCR method. Indeed, the detection of viral genome in environmental samples does not provide information about the infectivity (Girones et al. 2010), whereas this information is still of major importance in the evaluation of the human health risk.

The virus particles were concentrated from river water using a glass wool method with pre-acidification. This concentration method was chosen due to the relatively high volume of river water analysed (20 L). Moreover, a mean recovery of $57.1 \%$ (range $34.2 \%-78.2 \%$ ) (Wyn-Jones et al. 2011) has previously been obtained with surface water samples including samples from the same river than our study. This concentration method has been previously shown to allow the detection of infectious HAdVs (Wyn-Jones et al. 2011; Ogorzaly et al. 2013). Nevertheless, the $\mathrm{pH}$ range ( $\mathrm{pH} 4-9)$ used in primary concentration methods based on adsorption-elution using electronegative or electropositive filters such as glass wool method and also in concentration methods based on organic flocculation and celite may interfere with the detection of infectious viruses (Rames et al. 2016). Indeed, viral inactivation and aggregation may occur with such concentration methods (Rames et al. 2016; Gerba and Betancourt, 2017). Hollow fibre ultrafiltration (HFUF) is also adapted to large volume samples and used for primary concentration, but entrapment of viruses on the filter surface 
and inhibition of molecular methods from the use of sodium polyphosphate have been described with this method (Rames et al. 2016).

The genomes of HAdVs and HAdV41 were detected in all 15 river water samples and their concentrations ranged between 2 and $4 \operatorname{logs}$ gc/L. Such a high proportion of positive samples is in accordance with previous studies performed on the same river (Ogorzaly et al. 2009, 2013); prevalence of HAdVs about $90 \%$ has also been reported in surface water in other countries (Hamza et al. 2009; Garcia et al. 2012; Ye et al. 2012; Calgua et al. 2013a; Vieira et al. 2016; Farkas et al. 2018). The limitation of our sampling campaign to six months, the exclusion of the fall and early winter season and the lack of heavy rain or snow event within the two days prior to sampling may have contributed to the absence of strong variation between the viral genome concentrations. In a recent study performed on the river Ruhr (Germany) between July and September 2015, the authors observed that enhanced precipitation in combination with an increased flow rate were associated with an increase in the concentration of HAdVs (Mackowiak et al. 2018). HadVs are not known to show seasonal differences in their excretion resulting in lack of seasonality in raw wastewater (Rames et al. 2016). In a study performed in the river Ruhr with 184 samples collected between May 2012 and June 2013, no significant difference in the percentage of positive samples for HAdVs genome was observed between the bathing season $(92.5 \%, \mathrm{n}=80)$ and outside the bathing season $(88.5 \%, \mathrm{n}=104)$, suggesting a lack of seasonality of this enteric virus (Timm et al. 2016). Nevertheless, seasonal occurrence has been described in environmental waters in some cases (Rames et al. 2016). The discharge of treated wastewater from a large urban area ( 250,000 inhabitants) upstream from the sampling site had probably contributed to the high prevalence and concentrations observed in our study. Overall, considerable variations in prevalence and concentrations of HAdVs have been reported across studies. Indeed, $16 \%$ to $100 \%$ of surface water samples have been previously shown to be positive for HAdVs with concentrations ranging from 1 to 7 logs gc/L (Bofill-Mas et al. 2013; Iaconelli et al. 2017a). 
The high proportion of the enteric type HAdV41 (80\%) observed in our river water samples is in accordance with the few studies performed on surface water (Xagoraraki et al. 2007; Haramoto et al. 2007; Bofill-Mas et al. 2010; Ogorzaly et al. 2015; La Rosa et al. 2017). The use of the next-generation sequencing (NGS) technology which seems to be the most relevant method to study the diversity of HAdVs in environmental waters has recently shown that HAdV41 was the most abundant type in complex environmental matrices with high concentrations of HAdVs such as wastewater (Ogorzaly et al. 2015; Iaconelli et al. 2017b). All 15 river water samples were also positive for the genomes of NoV GGI and NoV GGII and the concentrations of NoV GGII were similar to those observed for HAdVs and HAdV41. In a recent study performed on the Seine River (France), HAdVs, NoV GGI and NoV GGII genomes have been detected in $93 \%, 88 \%$ and $92 \%$ of the samples $(n=100)$, respectively, and the impact of the wastewater treatment plant effluents on the viral contamination of the river has been clearly shown (Prevost et al. 2015). Overall, considerable variations between HAdVs and NoV have also been reported across studies. Highly different prevalence has been described in some studies (Wyn-Jones et al. 2011; Corsi et al. 2014; Vieira et al. 2016), whereas similar prevalence has been reported in others (Kishida et al. 2012; Prevost et al. 2015; Iaconelli et al. 2017a; Jones et al. 2017; La Rosa et al. 2017). Differences in prevalence between sampling sites have also been reported in the same study (Calgua et al., 2013a). Studies comparing the persistence of viral RNA and DNA are still needed (Bertrand et al., 2012), but similar concentrations for HAdV and NoV GGII genomes seem more likely to occur in case of a recent and / or high viral contamination.

The ICC-qPCR method used in the present work allowed the quantification of infectious HAdVs in one day with a sensitivity of $10 \mathrm{MPNCU} / \mathrm{L}$ of river water. A linear relationship between infectious dose and viral genome in infected cells at $T_{24 h}$ was observed between $10^{5}$ and $10 \mathrm{MPNCU} / \mathrm{L}$. A few studies have quantified infectious HAdVs naturally occurring in environmental waters and only a small part of them have used the ICC-qPCR 
method in such a context. Two studies carried out in Brazil have observed high concentrations of infectious HAdVs in groundwater, surface water (i.e. lagoon) and spring source water, but also in chlorinated water from a network distribution system using ICC-RT-qPCR (Fongaro et al. 2013, 2015). Thus, the authors have reported concentrations ranging from $10^{2}$ to $10^{3} \mathrm{gc} / \mathrm{L}$ of infectious HAdVs in $60 \%(3 / 5)$ to $80 \%(4 / 5)$ of groundwater samples and from $10^{2}$ to $10^{5}$ gc/L of infectious HAdVs in $83 \%$ (5/6) of water samples from a network distribution system (post chlorination). However, infectious HAdVs constituted $\leq 0.12 \%$ of total HAdVs in all these samples (Fongaro et al. 2015). Using ICC-RT-qPCR, Rodriguez et al. (2013) have detected infectious HAdVs at concentrations ranging between $10^{1}$ and $10^{3}$ mRNA-Infectious Units/L in sewage $(n=4)$ in the USA. The ratios between total and infectious HAdVs ranged from $11 / 1$ to $26 / 1$ for three samples containing HAdV-F species only. One sample showed a ratio of 381/1 and contained HAdVs belonging to A, E and F species. This meant that the first three samples contained between $3.8 \%$ and $9.1 \%$ of infectious HAdVs, whereas the last sample contained $0.2 \%$ of infectious HAdVs. Our concentrations $\left(10^{1}\right.$ to $10^{3}$ eqMPNCU/L) and percentages $(0.3 \%$ to $12.2 \%)$ of infectious HAdVs were similar to those observed in sewage (Rodriguez et al. 2013) but different from those detected by Fongaro et al. (2013, 2015). The delay between viral contamination and sampling may significantly impact the percentages of infectious HAdVs. The cell lines may also contribute to these discrepancies concerning the percentages of infectious HAdVs. Indeed, Fongaro et al. $(2013,2015)$ have used A549 cells, whereas Rodriguez et al. (2013) have used G293 cells. As discussed in the introduction, several studies have shown that A549 cells do not allow the detection of HAdV41 which is highly frequent in environmental samples. In the present study, infectious HAdV41 were found in $73 \%$ of the river water samples (11/15). Only two studies have described the detection or quantification of infectious HAdV41 in environmental waters and were performed on sewage. Infectious HAdV41 have been detected in all sewage samples in Luxembourg $(n=4)$ (Ogorzaly et al. 2015) and in the USA $(n=4)$ (Rodriguez et al. 2013). 
Above, the possibility of an inactivation of virus particles during the concentration step has been discussed. Rames et al. (2016) have reported in their review a comparison of HAdVs concentrations in raw and treated wastewater using culture-based and qPCR methods for different concentration methods; the percentages of infectious HAdVs ranged from $<0.01 \%$ to $10 \%$. Thus, our percentages of infectious HAdVs ( $0.3 \%$ to $12.2 \%)$ suggested that the glass wool method does not impact more deeply the infectivity of virus particles than PEG (polyethylene glycol) precipitation or ultracentrifugation. Overall, further studies on concentration methods adapted to large volume of surface water samples and considering both the recovery rates and the preservation of virus infectivity are still needed. These studies should focus on HAdV41. Intercalating dye treatment prior to qPCR, in particular EMAqPCR, seems to be a valuable method to evaluate capsid integrity in water matrices. It could be a rapid, relatively inexpensive and easy to use tool in the evaluation of the effect of concentration methods on the virus integrity (Leifels et al. 2016; Prevost et al. 2016). For ICC-qPCR approach, studies should take into account that specific cell lines such as 293 should be used and that HAdV41 might have a longer multiplication cycle than other HAdV types (Siqueira-Silva et al. 2009).

\section{Conclusions}

Our work shows that not only HAdV genomes but also infectious particles can be frequent in river water in Europe. Indeed, infectious HAdVs reached more than 10 infectious particles/L in more than $50 \%$ of the 15 samples. HAdV41 genome was highly predominant in these river samples and a correlation between HAdV41 and NoV GGII genomes was observed. The presence of these two enteric viruses should be studied in relation with effluent discharge in particular for rivers with a strong anthropic pressure. Infectious HAdV41 was detected with a frequency higher than $70 \%$. This predominance of HAdV41 genome over other HAdV types and the high prevalence of infectious HAdV41 in environmental waters underline the need for 
485 further studies focusing on the specific quantification of infectious particles of HAdV41. Such

486 data are needed to improve the knowledge on this enteric type and its potential as a viral

487 indicator of water quality.

488

489

Acknowledgements

490 The present work was financially supported by the Institut Jean Barriol (CNRS and Université

491 de Lorraine). Complementary financial support was obtained from Zone Atelier Moselle

492 (ZAM). The authors thank Romain Rivet for his excellent technical assistance in ddPCR

493 assays and Coline Wietrich for her contribution to the ddPCR analyses.

494

495 Conflict of interest

496 The authors declare that they have no conflict of interest.

497

498 


\section{References}

Bertrand I, Schijven JF, Sánchez G, Wyn-Jones P, Ottoson J, Morin T, Muscillo M, Verani M, Nasser A, de Roda Husman AM, Myrmel M, Sellwood J, Cook N, Gantzer C (2012) The impact of temperature on the inactivation of enteric viruses in food and water: a review. J Appl Microbiol 112:1059-7

Brié A, Razafimahefa R, Loutreul J, Robert A, Gantzer C, Boudaud N, Bertrand I (2017) The Effect of heat and free chlorine treatments on the surface properties of murine norovirus. Food Environ Virol 9:149-15

Bofill-Mas S, Albinana-Gimenez N, Clemente-Casares P, Hundesa A, Rodriguez-Manzano J, Allard A, Calvo M, Girones R (2006) Quantification and stability of human adenoviruses and polyomavirus JCPyV in wastewater matrices. Appl Environ Microbiol $72: 7894-6$

Bofill-Mas S, Calgua B, Clemente-Casares P, La Rosa G, Iaconelli M, Muscillo M, Rutjes S, de Roda Husman AM, Grunert A, Gräber I, Verani M, Carducci A, Calvo M, WynJones P, Girones R (2010) Quantification of human adenoviruses in European recreational waters. Food Environ Virol 2:101-109

Bofill-Mas S, Rusiñol M, Fernandez-Cassi X, Carratalà A, Hundesa A, Girones R (2013) Quantification of human and animal viruses to differentiate the origin of the fecal contamination present in environmental samples. Biomed Res Int:192089

Calgua B, Fumian T, Rusiñol M, Rodriguez-Manzano J, Mbayed VA, Bofill-Mas S, Miagostovich M, Girones R (2013a) Detection and quantification of classic and emerging viruses by skimmed-milk flocculation and PCR in river water from two geographical areas. Water Res 47:2797-810.

Corsi SR, Borchardt MA, Spencer SK, Hughes PE, Baldwin AK (2014) Human and bovine viruses in the Milwaukee River watershed: hydrologically relevant representation and relations with environmental variables. Sci Total Environ 490:849-60 
Farkas K, Cooper DM, McDonald JE, Malham SK, de Rougemont A, Jones DL (2018) Seasonal and spatial dynamics of enteric viruses in wastewater and in riverine and estuarine receiving waters. Sci Total Environ 634:1174-1183

Fongaro G, Nascimento MA, Rigotto C, Ritterbusch G, da Silva AD, Esteves PA, Barardi CR (2013) Evaluation and molecular characterization of human adenovirus in drinking water supplies: viral integrity and viability assays. Virol J 10:166

Fongaro G, Padilha J, Schissi CD, Nascimento MA, Bampi GB, Viancelli A, Barardi CR (2015) Human and animal enteric virus in groundwater from deep wells, and recreational and network water. Environ Sci Pollut Res Int 22:20060-6

Garcia LA, Viancelli A, Rigotto C, Pilotto MR, Esteves PA, Kunz A, Barardi CR (2012) Surveillance of human and swine adenovirus, human norovirus and swine circovirus in water samples in Santa Catarina, Brazil. J Water Health 10:445-52

Gassilloud B, Schwartzbrod L, Gantzer C (2003) Presence of viral genomes in mineral water: a sufficient condition to assume infectious risk? Appl Environ Microbiol 69:3965-9

Gerba CP, Betancourt WQ (2017) Viral aggregation: impact on virus behavior in the environment. Environ Sci Technol 51:7318-7325.

Gerrity D, Ryu H, Crittenden J, Abbaszadegan M (2008) UV inactivation of adenovirus type 4 measured by integrated cell culture qPCR. J Environ Sci Health A Tox Hazard Subst Environ Eng 43:1628-38

Girones R, Ferrús MA, Alonso JL, Rodriguez-Manzano J, Calgua B, Corrêa Ade A, Hundesa A, Carratala A, Bofill-Mas S (2010) Molecular detection of pathogens in water--the pros and cons of molecular techniques. Water Res 44:4325-39

Greening GE, Hewitt J, Lewis GD (2002) Evaluation of integrated cell culture-PCR (C-PCR) for virological analysis of environmental samples. J Appl Microbiol 93:745-50 
Hamza IA, Jurzik L, Stang A, Sure K, Uberla K, Wilhelm M (2009) Detection of human viruses in rivers of a densly-populated area in Germany using a virus adsorption elution method optimized for PCR analyses. Water Res 43:2657-68

Haramoto E, Katayama H, Oguma K, Ohgaki S (2007) Quantitative analysis of human enteric adenoviruses in aquatic environments. J Appl Microbiol 103:2153-9

Hernroth BE, Conden-Hansson AC, Rehnstam-Holm AS, Girones R, Allard AK (2002) Environmental factors influencing human viral pathogens and their potential indicator organisms in the blue mussel, Mytilus edulis: the first Scandinavian report. Appl Environ Microbiol 68:4523-33

Iaconelli M, Muscillo M, Della Libera S, Fratini M, Meucci L, De Ceglia M, Giacosa D, La Rosa G (2017a) One-year surveillance of human enteric viruses in raw and treated wastewaters, downstream river waters, and drinking waters. Food Environ Virol. 9:7988

Iaconelli M, Valdazo-González B, Equestre M, Ciccaglione AR, Marcantonio C, Della Libera S, La Rosa G (2017b) Molecular characterization of human adenoviruses in urban wastewaters using next generation and Sanger sequencing. Water Res 121:240-247

Ibrahim C, Hassen A, Pothier P, Mejri S, Hammami S (2018) Molecular detection and genotypic characterization of enteric adenoviruses in a hospital wastewater. Environ Sci Pollut Res Int 25:10977-10987.

International Organization for Standardization. 2013. ISO/TS 152616-1:2013. Microbiology of the food chain--Horizontal method for determination of hepatitis A virus and norovirus using real-time RT-PCR--Part1: Method for quantification. https://www.iso.org/standard/65681.html

Jones TH, Brassard J, Topp E, Wilkes G, Lapen DR (2017) Waterborne viruses and F-specific coliphages in mixed-use watersheds: microbial associations, host specificities, and 
affinities with environmental/land use factors. Appl Environ Microbiol 83, pii: e02763-16

576 Kishida N, Morita H, Haramoto E, Asami M, Akiba M (2012) One-year weekly survey of noroviruses and enteric adenoviruses in the Tone River water in Tokyo metropolitan area, Japan. Water Res 46:2905-10

Ko G, Cromeans TL, Sobsey MD (2003) Detection of infectious adenovirus in cell culture by mRNA reverse transcription-PCR. Appl Environ Microbiol 69:7377-84.

Kosulin K, Geiger E, Vécsei A, Huber WD, Rauch M, Brenner E, Wrba F, Hammer K, Innerhofer A, Pötschger U, Lawitschka A, Matthes-Leodolter S, Fritsch G, Lion T (2016) Persistence and reactivation of human adenoviruses in the gastrointestinal tract. Clin Microbiol Infect 22:381.e1-381.e8

La Rosa G, Pourshaban M, Iaconelli M, Muscillo M (2010) Quantitative real-time PCR of enteric viruses in influent and effluent samples from wastewater treatment plants in Italy. Ann Ist Super Sanita 46:266-73

La Rosa G, Sanseverino I, Della Libera S, Iaconelli M, Ferrero VEV, Barra Caracciolo A, Lettieri T (2017) The impact of anthropogenic pressure on the virological quality of water from the Tiber River, Italy. Lett Appl Microbiol. 65:298-305.

Lee C, Lee SH, Han E, Kim SJ (2004) Use of cell culture-PCR assay based on combination of

Lee SH, Lee C, Lee KW, Cho HB, Kim SJ (2005) The simultaneous detection of both enteroviruses and adenoviruses in environmental water samples including tap water A549 and BGMK cell lines and molecular identification as a tool to monitor infectious adenoviruses and enteroviruses in river water. Appl Environ Microbiol 70:6695-705 with an integrated cell culture-multiplex-nested PCR procedure. J Appl Microbiol 98:1020-9 
Leifels M, Hamza IA, Krieger M, Wilhelm M, Mackowiak M, Jurzik L (2016) From lab to lake - Evaluation of current molecular methods for the detection of infectious enteric viruses in complex water matrices in an urban area. PLoS One 11:e0167105

Li F, Feng L, Liu Y, Zhen X, Chen L (2009) An integrated cell culture and quantitative polymerase chain reaction technique for determining titers of functional and infectious adenoviruses. Anal Biochem 391:157-9

Mena KD, Gerba CP (2009) Waterborne adenovirus. Rev Environ Contam Toxicol. 198:133-67

Ogorzaly L, Tissier A, Bertrand I, Maul A, Gantzer C (2009) Relationship between F-specific RNA phage genogroups, faecal pollution indicators and human adenoviruses in river water. Water Res 43:1257-64

Ogorzaly L1, Bertrand I, Paris M, Maul A, Gantzer C (2010) Occurrence, survival, and persistence of human adenoviruses and F-specific RNA phages in raw groundwater. Appl Environ Microbiol 76:8019-25

Ogorzaly L, Cauchie HM, Penny C, Perrin A, Gantzer C, Bertrand I (2013) Two-day detection of infectious enteric and non-enteric adenoviruses by improved ICC-qPCR. Appl Microbiol Biotechnol 97:4159-66

Ogorzaly L, Walczak C, Galloux M, Etienne S, Gassilloud B, Cauchie HM (2015) Human Adenovirus diversity in water samples using a next-generation amplicon sequencing approach. Food Environ Virol 7:112-121

Prevost B, Lucas FS, Goncalves A, Richard F, Moulin L, Wurtzer S (2015) Large scale survey of enteric viruses in river and waste water underlines the health status of the local population. Environ Int 79:42-50

Prevost B, Goulet M, Lucas FS, Joyeux M, Moulin L, Wurtzer S (2016) Viral persistence in surface and drinking water: Suitability of PCR pre-treatment with intercalating dyes. Water Res 91:68-76 
Rames E, Roiko A, Stratton H, Macdonald J (2016) Technical aspects of using human adenovirus as a viral water quality indicator. Water Res 96:308-26

Rodríguez RA, Polston PM, Wu MJ, Wu J, Sobsey MD (2013) An improved infectivity assay combining cell culture with real-time PCR for rapid quantification of human adenoviruses 41 and semi-quantification of human adenovirus in sewage. Water Res $47: 3183-91$

Rodríguez-Lázaro D1, Cook N, Ruggeri FM, Sellwood J, Nasser A, Nascimento MS, D'Agostino M, Santos R, Saiz JC, Rzeżutka A, Bosch A, Gironés R, Carducci A, Muscillo M, Kovač K, Diez-Valcarce M, Vantarakis A, von Bonsdorff CH, de Roda Husman AM, Hernández M, van der Poel WH (2012) Virus hazards from food, water and other contaminated environments. FEMS Microbiol Rev 36:786-814

Rusiñol M, Fernandez-Cassi X, Timoneda N, Carratalà A, Abril JF, Silvera C, Figueras MJ, Gelati E, Rodó X, Kay D, Wyn-Jones P, Bofill-Mas S, Girones R (2015) Evidence of viral dissemination and seasonality in a Mediterranean river catchment: Implications for water pollution management. J Environ Manage 15:159:58-67

Ryu H, Cashdollar JL, Fout GS, Schrantz KA, Hayes S (2015) Applicability of integrated cell culture quantitative PCR (ICC-qPCR) for the detection of infectious adenovirus type 2 in UV disinfection studies. J Environ Sci Health A Tox Hazard Subst Environ Eng $50: 777-87$

Shih YJ, Tao CW, Tsai HC, Huang WC, Huang TY, Chen JS, Chiu YC, Hsu TK, Hsu BM (2017) First detection of enteric adenoviruses genotype 41 in recreation spring areas of Taiwan. Environ Sci Pollut Res Int In Press

Siqueira-Silva J, Yeda FP, Favier AL, Mezin P, Silva ML, Barrella KM, Mehnert DU, Fender P, Hársi CM (2009) Infection kinetics of human adenovirus serotype 41 in HEK 293 cells. Mem Inst Oswaldo Cruz 104:736-44 
Timm C, Luther S, Jurzik L, Hamza IA, Kistemann T (2016) Applying QMRA and DALY to assess health risks from river bathing. Int J Hyg Environ Health 9:681-692

Vieira CB, de Abreu Corrêa A, de Jesus MS, Luz SL, Wyn-Jones P, Kay D, Vargha M, Miagostovich MP (2016) Viruses surveillance under different season scenarios of the Negro river basin, Amazonia, Brazil. Food Environ Virol 8:57-69

Wyn-Jones AP, Carducci A, Cook N, D'Agostino M, Divizia M, Fleischer J, Gantzer C, Gawler A, Girones R, Höller C, de Roda Husman AM, Kay D, Kozyra I, López-Pila J, Muscillo M, Nascimento MS, Papageorgiou G, Rutjes S, Sellwood J, Szewzyk R, Wyer M (2011) Surveillance of adenoviruses and noroviruses in European recreational waters. Water Res 45:1025-38

Xagoraraki I, Kuo DH, Wong K, Wong M, Rose JB (2007) Occurrence of human adenoviruses at two recreational beaches of the great lakes. Appl Environ Microbiol. $73: 7874-81$

Ye XY, Ming X, Zhang YL, Xiao WQ, Huang XN, Cao YG, Gu KD (2012) Real-time PCR detection of enteric viruses in source water and treated drinking water in Wuhan, China. Curr Microbiol 65:244-53 
667

668 Figure 1. Genome concentrations of HAdVs, HAdV41, NoV GGI and NoV GGII in the river 669 water samples $(n=15)$ using ddPCR.

670

671 Figure 2. Standard curve of the ICC-qPCR assay generated from the range of dilutions of $672 \operatorname{HAdV} 2(\mathrm{n}=17 \times 2)$.

673

674

Figure 3. Relation between the concentrations of (a) HAdVs and HAdV41, (b) NoV GGII 675 and HAdV41, and (c) NoV GGII and NoV GGI in the 15 river water samples.

676

677

Figure 4. Concentrations of HAdV genomes and infectious HAdVs in the river water samples

678 ( $\mathrm{n}=15)$ using ddPCR and ICC-qPCR, respectively. Samples positive for infectious HAdV41

679 are notified with an asterisk. ND: not detected. NQ: not quantified.*: water samples positive 680 for infectious HAdV41.

681

682

683

Supplementary material

684

Figure 1. Sampling point in the river Meurthe in the metropolitan area of Nancy. Black

685 arrow: discharge of treated wastewater in the river. Red star: sampling point in the river 686 